\title{
Contributor's Page
}

\author{
Volume 3, Spring 2015
}

http://dx.doi.org/10.3998/mjs.12333712.0003.012

Dorothy H. Anderson, Ph.D., is an Emeritus Professor in the Department of Forest Resources at the University of Minnesota. For over 35 years, Dr. Anderson's research has focused on quantifying how outdoor recreation resources provide benefits to individuals, local communities and their economies, and society. Dr. Anderson is an advocate for integrating 'place' and local stakeholders' values, opinions, beliefs and attitudes into formal natural resource management and land use planning systems. Currently, Dr. Anderson is traveling the world, enjoying the life of a newly retired faculty member; she is also making plans to hike the entirety of the Camino de Santiago in 2016.

Nathalie Beauvais, APA, MOAQ, Intl. Assoc. AIA, LEED AP is a senior member of Kleinfelder's sustainability practice where she currently manages the team of scientists, academics and sustainability experts conducting the City of Cambridge Climate Change Vulnerability Assessment and Adaptation Plan, the Massport Disaster Infrastructure and Resiliency Planning Study and the Washington DC Adaptation Plan. An author and speaker on comprehensive planning, sustainable planning and climate change, Ms. Beauvais is an adjunct professor at Northeastern University in the Master Program in Design for Environmental Planning. Ms. Beauvais received her Master of Architecture from Harvard University and her Baccalaureate in Architecture from Laval University in Quebec."

Karly Bitsura-Meszaros is a PhD student in the Department of Parks, Recreation and Tourism Management at NC State University. Her research is focused on climate change and its potential impacts on nature-based recreation participation, visitors' risk perceptions, and natural resource management agencies.

Hua Cai is a PhD candidate pursuing a joint degree in School of Natural Resources and Environment and Department of Civil and Environmental Engineering at the University of Michigan. Her current research studies the environmental implications of electric vehicles using big-data informed travel patterns. She has published 
in several journals including Environmental Science and Technology, Transportation Research Part D, and Journal of Industrial Ecology. She received her MS and BS both in Environmental Engineering from the Pennsylvania State University and Tsinghua University in 2007 and 2005, respectively.

John Callewaert, the Integrated Assessment (IA) Program Director of the Graham Institute, is responsible for designing, implementing, and overseeing the day-to-day operations of translational knowledge efforts which actively involve subject matter experts, decision makers, and key stakeholders in outlining viable pathways toward sustainability solutions. In addition to his work with the IA Program, he is an instructor for UC 327: Sustainability Scholars Interdisciplinary Thinking - the junior level course for the Graham Sustainability Scholars program - and serves as the coprincipal investigator for the Sustainability Cultural Indicators Program - a six-year longitudinal study in collaboration with U-M Institute for Social Research that assesses sustainability knowledge, behaviors, and attitudes across U-M students, faculty, and staff over time to inform educational programs and campus operations. John also serves as an associate editor for the Journal of Environmental Studies and Sciences and as an advisory board member for The Integrated Assessment Society. He earned a B.S. in Agricultural Engineering Technology from Michigan State University and his Ph.D. from the School of Natural Resources and Environment at UM-Ann Arbor.

Nick Caverly is a PhD student in Sociocultural Anthropology at the University of Michigan. His research examines the forms of social, material, and logistical infrastructure necessary for disassembling vacant buildings in Detroit. This research is funded by the Social Science Research Council. Before coming to Michigan he earned an MA in anthropology from The New School where he also taught in the interdisciplinary design history and theory program.

Melissa Daigle is a Research Associate and Resiliency Specialist with the Louisiana Sea Grant Law \& Policy Program, located at Louisiana State University. Her current research focuses on assisting local governments and residents prepare for coastal hazards and understand changes to programs that directly impact them, such as the recent changes to the National Flood Insurance Program. Additionally, she oversees six legal interns who are interested in practicing in the field of environmental law. She received a Juris Doctorate and a Bachelor of Civil Law from the Paul M. Hebert School of Law at Louisiana State University in 2008, a Master of Arts from Louisi- 
ana State University in 2005, and a Bachelor of Arts from Nicholls State University in 2003.

Mae Davenport is an Associate Professor of Human Dimensions of Natural Resources and the Environment in the Department of Forest Resources and Director of the Center for Changing Landscapes at the University of Minnesota (UMN). Her research focuses on two areas: (1) human beliefs, attitudes and behaviors related to natural systems and (2) community capacity for sustainable natural resource and environmental management. She teaches courses in sustainable land use planning and policy, social science research methods, and park and protected area management to undergraduate and graduate students at UMN.

Robyn d'Avignon is a $\mathrm{PhD}$ candidate in the Interdepartmental Program in Anthropology and History at the University of Michigan. Her research explores competition for land, resource rights, and legal protection among rural communities and multinational mining companies in West Africa. She also holds a certificate in Science, Technology, and Society from Michigan and a Bachelor of Arts from Washington University in St. Louis.

Jonathon Day is an Associate Professor in the School of Hospitality and Tourism Management at Purdue University. His current research focuses on sustainable tourism and destination/community development and resilience. He is Chair of the Knowledge, Networking, Education and Training Working Group for the Global Sustainable Tourism Council. He received a PhD from James Cook University ( Australia), a MBA from UCLA and a Bachelor of Business from Queensland University of Technology.

Devki Desai is currently a structural designer at Skidmore, Owings and Merrill, and recently concluded her NSF fellowship at the University of Michigan focusing on development of thermally adaptive building materials at the ACE-MRL laboratory. She was the founding project manager of the BLUElab LBC team and continues to work with the group. Devki has shared her work at the first International Conference on Concrete Sustainability and in the Journal of Construction and Building Materials. She received an M.S.E in Structural Engineering from the University of Michigan and a B.A. in Environmental Science from Washington University in St. Louis. 
Lisa Dickson, PG, Vice President of Sustainability, has expertise in regulations and financial markets related to carbon and renewable energy, and risk assessment as it relates to sustainability and climate change. She was a contributor to the World Resource Institute's 2010 Public Sector GHG Protocol and aided in development of the Institute for Sustainable Infrastructure's (ISI) project rating system. In 2010, she was invited to Shanghai to comment on China's 12th 5-Year Plan and present on the use of carbon markets to drive investment within the transportation sector. Currently, she is leading multiple climate change projects including work for the City of Cambridge, Massachusetts, the Army National Guard, several South Shore (MA) municipalities, and Massport's Disaster and Infrastructure Resiliency Plan. Ms. Dickson received her MS in Geological Sciences from University of Michigan.

Chase Dwelle is a PhD student in the Environmental Engineering Program at the University of Michigan. His current research is centered around quantifying uncertainty in hydrological models, focusing on erosion and urban flooding. He received a Master of Civil Engineering and and Bachelors of Civil \& Environmental Engineering from the University of Michigan.

James Erbaugh is a PhD Candidate at the School of Natural Resource and Environment at the University of Michigan. His research focuses on how multifunctional forest landscapes affect forest cover and rural livelihoods in Indonesia. To complete this work, he has received grants from the Social Science Research Council and the U.S. Fulbright program, as well as a Borlaug Fellowship. James received his Master of Philosophy in Geography and Environment from the University of Oxford, and a Bachelor of Arts in Philosophy and Environmental Policy from Miami University.

Gillian Galford is an earth systems scientist interested in deforestation and landuse change and its impacts on climate, carbon, and nitrogen. In Vermont, Dr. Galford has led the Vermont Climate Assessment to evaluate impacts of climate change in the state. Her expertise is in spatial analysis, applying tools of remote sensing and ecosystems modeling. She has worked on carbon and nitrogen dynamics in a range of settings, from the large-scale soybean farms of Mato Grosso, Brazil, to small-holder agricultural systems of Malawi and East Africa. In addition to these research projects, Gillian teaches courses at the Gund Institute. Previously, she was a Postdoctoral Research Fellow at the Earth Institute of Columbia University and The Woods Hole Research Center. Gillian taught the course on the Vermont Climate Assessment and was lead author of the report. 
Dr. Indrani Ghosh received a Doctorate in Civil Engineering from Northeastern University and a Masters in Environmental Engineering from Indian Institute of Technology in Kanpur. Dr. Ghosh has expertise in climate change vulnerability assessments and resiliency work for municipalities, transportation authorities and military installations in the greater Boston area. She has been involved with translating climate change science into engineering design criteria in both academic and industry-leading research in collaboration with multiple entities, including municipalities, state agencies, and academic collaborators. She served on the sea level rise subcommittee of the Massachusetts Environmental Policy Act (MEPA) Adaptation Advisory Committee and is serving as a reviewer for the American Society of Civil Engineers (ACSE) Journal of Environmental Engineering.

Beth Gibbons is the director of the University of Michigan's Climate Center. The U-M Climate Center is dedicated to supporting the long-term sustainability of the Great Lakes region in the face of climate change and facilitating smart decisionmaking, backed by scientific knowledge. Beth is also the Program Manager of NOAA's Great Lakes regional RISA, GLISA. In both roles her core responsibilities include fostering the transfer of information on climate change and resilience from the research community to stakeholders throughout the region. Beth holds a graduate degree in Urban and Regional Planning from the University of Michigan.

Ashlee Grace, the Urban Adaptation Project Manager at the University of Michigan's Climate Center, is responsible for providing place-based information needed for developing and improving policy decisions and infrastructure investments related to climate adaptation in the Great Lakes region. Ashlee's work includes fostering the transfer of information on climate change and community and economic resilience from the research side at the University of Michigan (U-M) to city stakeholders throughout the region. Ashlee's previous experiences include working in the fields of land conservation, community health, and climate education and communication. She holds two Masters degrees from the University of Michigan, including an M.S. in Natural Resource and Environmental Management and an M.U.P. in Urban and Regional Planning, and a Bachelor of Arts in Sociology from New York University. Ashlee's work focuses on the intersection and management of natural, built and social systems in the face of a changing climate.

Jessica Grannis is the Adaptation Program Manager for the Georgetown Climate Center and is a staff attorney and adjunct professor at the Harrison Institute for 
Public Law, at Georgetown University Law Center. Ms. Grannis oversees staff and student research and analysis of federal, state and local adaptation efforts. Her recent publications include an Adaptation Tool Kit for Sea Level Rise (2012) and a book chapter on Coastal Retreat in the Law of Adaptation to Climate Change: U.S. and International Aspects (2012, with Peter Byrne). Prior to joining the Harrison Institute, she was staff counsel for the California State Coastal Conservancy and the Ocean Protection Council. She holds a B.A. in history from the University of Chicago; a J.D. , Cum Laude, from University of California Hastings College of the Law; and a L.L.M, with honors, from Georgetown Law.

Patrick Harlin is a DMA candidate in Music Composition at the University of Michigan. His dissertation investigates sound and sustainability and the preservation of sonic landscapes focusing on remote regions of the Amazon rainforest and Book Cliffs, Utah. Patrick's compositions have been performed by the St. Louis Symphony, Calgary and Rochester Philharmonic Orchestras, Atlantic Classical Orchestra, and Alarm Will Sound among others with upcoming premieres by the Calidore String Quartet. He received a Master's in composition from the University of Michigan and bachelor's from Western Washington University.

Christopher Hoving is the Adaptation Specialist at the Michigan Department of Natural Resources. He is the program lead for the DNR Wildlife Division in adapting wildlife management to emerging issues, such as a changing climate. He currently serves as the chair of the Climate Change and Wildlife Working Group of The Wildlife Society. He received his Master of Wildlife Ecology from the University of Maine and his Bachelor of Science in Fish and Wildlife from Michigan State University.

Thomas Jenkinson is a $\mathrm{PhD}$ candidate in Ecology and Evolutionary Biology at the University of Michigan. His dissertation research is focused on using genetic tools to track the movement of newly discovered wildlife diseases. Thomas is currently conducting field work on amphibian conservation and biodiversity in southeastern Brazil, and was recently appointed to the Education Committee of the Mycological Society of America. He received an M.S. in Ecology and Systematic Biology from San Francisco State University, and a B.S. in Biology from Oregon State University.

Mark Kanazawa is a Professor in the Department of Economics at Carleton College. His research focuses on the economics of water and water law. He is former 
chair of the economics department and director of environmental studies at Carleton College. He received his $\mathrm{PhD}$ in Economics from Stanford University and a Bachelor of Arts from Earlham College.

Shamitha Keerthi is a $\mathrm{PhD}$ candidate and Dow Doctoral Fellow in the School of Natural Resources and Environment at the University of Michigan. Her current research evaluates the water quality impacts from agricultural land-use change as a result of the US biofuels mandate.She received a M.S in Environmental Science and Engineering from the Singapore Stanford Partnership Programme (Stanford, US - NTU, Singapore) and a B.E in Chemical Engineering from the Vishveshvaraya Technological University (Bangalore, India).

Yong Kim is a PhD candidate at the University of Michigan's Ross School of Business. He studies how sustainability-related issues influence the global supply chain network in the mobile handset industry. He received a MA and BA in Sociology from Yonsei University.

Rebecca Mandell is a PhD candidate at the University of Michigan School of Public Health. Her research focuses on advocacy efforts at the intersection of environmental justice and reproductive justice that aim to protect vulnerable communities from toxicants harmful to reproductive health. She was recently awarded a fellowship by the University of Michigan's Institute for Research on Women and Gender and Rackham Graduate School. She holds an MS from the Harvard School of Public Health and a BA from Harvard University.

Allie McCreary is a Research Assistant and PhD student at NC State University. Allie is interested in exploring agency and community capacity to respond to changes in climate, recreation preferences, and tourism trends in nature-based settings. Allie is also exploring the role of geovisualization technologies to collect and communicate human dimensions of natural resources data. She obtained her BS and MS in Forestry at Southern Illinois University.

Sara Meerow is a Ph.D. candidate at the University of Michigan's School of Natural Resources and Environment (SNRE). Her research generally focuses on questions related to building urban resilience in the face of climate change. Her dissertation examines the political and scalar dimensions of using green infrastructure to foster resilience in the vulnerable coastal megacities of Manila, New York City, and Los 
Angeles. Sara received her Master's in International Development Studies from the University of Amsterdam and a bachelor of Arts in Political Science and History from the University of Florida.

Cynthia Messer is an Extension Professor with the University of Minnesota Tourism Center. She has more than 35 years of tourism experience as both an educator and practitioner. Her work focuses on community-level sustainable tourism development and quality customer service. She received a Master of Arts in Education and Human Development from George Washington University, and a Bachelor of Arts from University of California, Los Angeles.

Sarah Mills is postdoctoral fellow in the Center for Local, State, and Urban Policy (CLOSUP) at the University of Michigan's Gerald R. Ford School of Public Policy. In addition to managing two large-scale surveys, her own research focuses on the impact that wind energy projects have on owners of farmland and farming communities more generally. She has a PhD in Urban and Regional Planning from the University of Michigan, a Master of Philosophy in Engineering for Sustainable Development from the University of Cambridge (UK), and a Bachelor of Science in Mechanical Engineering from Villanova University.

Julie Nash is Research Leader at the CGIAR Research Program on Climate Change, Agriculture and Food Security (CCAFS) at the Gund Institute at the University of Vermont. Julie's research focuses on the interface between business development, environmental behaviors, and natural capital. Her dissertation research at UVM focused on sustainable development in the marine cultured-pearl industry. Prior to starting at UVM, Julie spent most of her career at international consumer products companies, working in various management capacities in brand marketing, strategic planning, and corporate finance. Most recently, Julie managed global innovation and new product development at Ben \& Jerry's in Burlington Vermont.

John Nieber received his B.S. degree in Forest Engineering at Syracuse University in 1972, his M.S. degree in Civil and Environmental Engineering at Cornell University in 1974, and his Ph.D. in Agricultural Engineering at Cornell University in 1979. He is currently Full Professor at the University of Minnesota in the Department of Bioproducts and Biosystems Engineering. John's research interests involve hydrologic process discovery and modeling, flow and transport processes in porous 
media, process design in ecological engineering, sustainability of water resource systems, and watershed restoration.

John R. Nordgren is Senior Advisor for The Kresge Foundation, where his work is focused on advancing special initiatives in support of community-based climate change adaptation. He previously served a Senior Program Officer for Kresge's Environment Program, leading development and implementation of the Foundation's strategies for advancing the field of Climate Change Adaptation. He is a member of the National Academy of Sciences Board on Atmospheric Sciences and Climate (BASC) and has worked closely with the White House Council on Environmental Quality in support of the Administration's Climate Adaptation Task Force. John holds degrees in public policy from The American University in Washington, D.C. and Tufts University in Medford, MA. He currently lives and works near Seattle, WA.

Michael Notaro is the Associate Director and Senior Scientist of the Nelson Institute Center for Climatic Research at the University of Wisconsin-Madison. His expertise includes land-ocean-atmosphere interactions, climate change impacts on ecosystems, dynamical downscaling, hydrology of the Great Lakes Basin, lake-effect snow, monsoon dynamics, and dust storm mechanisms. He is a member of the Climate Working Group of the Wisconsin Initiative on Climate Change Impacts (WICCI). He received a PhD in atmospheric sciences in 2002 from the State University of New York at Albany.

Jordan Occena is a Ph.D. pre-candidate in the Materials Science \& Engineering department at the University of Michigan. His work on the U-M Living Buildings Team has focused on system design and regulatory approval for residential rainwater collection and distribution, and he currently serves as the team's technical manager. He received a Bachelor of Science in Engineering Physics from the University of Tulsa.

Shaun O'Neil is a Geographer at King County's Wastewater Treatment Division. His current work focuses on how the effects of climate change will impact the infrastructure and operations of the wastewater treatment system that serves the Seattle metropolitan area. He received degrees in Geography and History from the University of Washington. 
Elizabeth Palchak is a PhD student at the Rubenstein School of Natural Resources at the University of Vermont and a Graduate Fellow at the Gund Institute. She is also a fellow in the Office of Sustainability at UVM, focused on socially responsible investing. Her dissertation work is on the social side of renewable energy transitions. She explores the role of human behavior in energy use and the development of effective energy policies, including the role of the smartgrid in facilitating information for energy consumers. She is also studying the framing of the fossil fuel divestment movement and the language used to support various political positions. On the Vermont Climate Assessment, she researched and wrote the chapter on energy.

John Phillips is the Combined Sewer Overflow Program Manager at King County Department of Natural Resources and Parks, Seattle, Washington. He has studied the impact of climate change on wastewater infrastructure for the last six years including the impacts of sea-level rise, temperature and precipitation. He is currently the Vice President of the Pacific Northwest Clean Water Association and has been a member of the Washington State Department of Ecology sea level rise working group and is an Envision Sustainability Professional. He received a Bachelor of Science from Oregon State University.

Aaron Ray is an Institute Associate at the Georgetown Climate Center where he provides adaptation policy analysis. His past work has focused on international, federal, state, and local adaptation policy; adaptation in the water, energy, and coastal sectors; climate finance; and green infrastructure. He is currently pursuing a Ph.D. in Political Science at American University, writing a dissertation on the politics of climate change adaptation. Aaron earned an M.P.P. in environmental and regulatory policy from the McCourt School of Public Policy at Georgetown University. He holds a B.A. in Philosophy from Linfield College.

Catherine Riseng is an Assistant Research Scientist at the School of Natural Resources and Environment (SNRE) and Research Program Manager at Michigan Sea Grant, both at the University of Michigan. As a research scientist she studies a broad range of ecological and environmental issues from how changes in land use hierarchically influence stream ecosystems to the effect of invasive species on the Great Lakes ecosystem. Her current research includes multi-disciplinary, collaborative projects that link watershed landscape conditions to Great Lakes tributaries and coastal ecosystems and has recently published in the Journal of Great Lakes Re- 
search. She received her PhD from SNRE in Aquatic Ecology, a Master's of Science in Limnology and a Bachelor of Arts in Botany.

Hannah Rockwell is a senior Environmental Engineering student at the University of Michigan. Her current work focuses on net zero water issues and sustainable infrastructure. Following graduation in May 2015 she will be pursuing a career in Water Resources Engineering.

Amy Samples is a Coastal Resilience Specialist at Michigan Sea Grant, based in Ann Arbor, Michigan. She is currently engaged in a small harbor sustainability project in collaboration with partners at the State of Michigan. She previously lead a climate project supported by the Great Lakes Integrated Sciences and Assessments (GLISA) Program and coordinated the Great Lakes Green Marina Outreach and Education Project, a regional collaboration of Great Lakes Clean Marina programs. She received a Master of Science from the University of Michigan School of Natural Resources and Environment and a Bachelor of Science from Clemson University.

Cathie Scott is a Water Quality Planner at the King County Wastewater Treatment Division in Seattle, Washington. Her current duties include researching, writing, and editing articles, reports, and other documents for a wide variety of audiences. She also works to incorporate equity and social justice in division projects. She is a $\mathrm{PhD}$ candidate and received a Master of Education degree in Educational Communication and Technology from the University of Washington and a Bachelor of Science degree in English from the University of Wisconsin.

Dr. Erin Seekamp is an Associate Professor and Department Extension Leader in the Department of Parks, Recreation and Tourism Management at North Carolina State University. Her research and teaching focus on partnerships, capacity building and decision-making, as well as environmental communications and behaviors, for natural resource conservation and sustainable tourism development.

Tracie Sempier is the Coastal Storms Outreach Coordinator for the MississippiAlabama Sea Grant Consortium and the Regional Program Manager for the Gulf of Mexico Alliance. She works with a variety of audiences to decrease the negative impacts of coastal storms on families, communities, property, and natural resources. She recently received the Gulf Guardian Award for her resilience work at the local, 
state, and regional levels. She completed a Ph.D. in Curriculum and Instruction at Mississippi State University, a M.S. in Science and Mathematics Education at Oregon State University, and a B.S. in Marine Science and Biology at the University of Alabama.

Jordan W. Smith, Ph.D., is an Assistant Professor of Natural Resource Social Science and GIS at NC State University. He is also a Faculty Fellow within the College of Natural Resources' Center for Geospatial Analytics. His research examines how humans make behavioral and planning adaptations in response to rapidly changing environmental conditions. He uses stated preference experiments, geospatial modeling and immersive virtual environments to understand contingent behaviors and preferences.

Lauren Stadler is a $\mathrm{PhD}$ candidate in Environmental Engineering at the University of Michigan studying biological wastewater treatment. Her research is focused on improving the energy balance of wastewater treatment and its impact on pharmaceutical removal during treatment. Through a combination of experimental work and systems analyses, she aims to understand inherent tradeoffs between energy efficiency and pharmaceutical contamination. Lauren received her M.S. in Environmental Engineering from the University of Michigan and her B.S. in Engineering from Swarthmore College. Lauren also worked in environmental consulting designing algae pond systems for wastewater treatment and received a Fulbright Scholarship to do research in New Delhi, India.

Richard Stedman is an associate professor with the Department of Natural Resources at Cornell University, Ithaca, New York. His research examines the sustainability of resource-dependent communities, especially as they transition to natural resource-based tourism development, environmental risk perception and management at the community level, causes and consequences of land-use change on the urban-rural fringe, natural resource-based decision making among private landowners; and (v) socio-ecological factors that underlie attachment to place. He received a Ph.D. in sociology from the University of Wisconsin.

Missy Stults is a PhD candidate and researcher in the Urban and Regional Planning Program and the School of Natural Resources and Environment at the University of Michigan. Her research and work focuses on helping cities to build their resilience to climate change and natural disasters. Missy is a founding member of the Ameri- 
can Society of Adaptation Professionals, a member of the Great Lakes Adaptation Assessment for Cities team, and a frequent consultant on local climate adaptation initiatives. Missy holds a Masters of Arts in Climate and Society from Columbia University and a Bachelors of Science in both Marine Biology and Environmental Science from the University of New England.

Adam Wellstead has been an assistant professor with the Department of Social Sciences at Michigan Technological University, Houghton, Michigan since 2011. Before then, he worked for Natural Resources Canada in Edmonton, Alberta for 16 years. His research interests include climate change adaptation, policy capacity, and survey research. He received a Ph.D from the University of Alberta's Department of Renewable Resources.

Bruce Wilson is a Professor in the Department of Bioproducts and Biosystems Engineering at the University of Minnesota and is a Center-for-Transportation-Studies Scholar. He has extensive modeling and experimental background in erosion mechanics and in hydrologic/water quality and has been the instructor for numerous undergraduate and graduate courses. He is the recipient of the Distinguished Graduate Teaching Faculty Award and the Distinguished Undergraduate Teaching Faculty Award given by College of Food, Agricultural and Natural Resource Sciences, University of Minnesota. He is a Fellow of the American Society of Agricultural and Biological Engineers. 